\title{
AN ANALYSIS OF MASLOW'S HIERARCHY OF NEED IN THE GREAT GATSBY NOVEL BY FRANCISS SCOTT FITZGERALD'S
}

\author{
Ritna Bahuwa \\ English Literature Department, Faculty of Cultural Science, \\ Muhammadiyah University of Gorontalo \\ ritnabahuwa@gmail.com
}

\begin{abstract}
This research discussed about the main character's need, Jay Gatsby. Namely, psychological need, safety need, love and belonging need, Esteem need, and actualization need. The objective of this research is to analyzed the Abraham Maslow's hierarchy need described in the Gatsby novel by Francis Scott Key Fitzgerald. This research used descriptive qualitative method and Abraham Maslow's theory. The result of this research was found from five types of Abraham Maslow's need, there were two types that were not fulfilled by Jay Gatsby, namely safety need, and love and belongingness need so, that actualization needs could not be reached.
\end{abstract}

Keywords: Jay Gatsby, Abraham Maslow's Hierarchy of Needs.

\section{INTRODUCTION}

Literature is a piece of writing which expresses and communicates through feeling and human attitude in literary work. We find many kinds of work that may contain anything which can be found in our life. It is in accordance with what Wellek and Warren (1993), said literary critics see literature as a product of human creativity in form of written or oral work. When we talk about literature, we consider that it is an endless topic of discussion. We can find many lessons about life. Literary work can be portraying of the author's life. By their works, they can express his/her imagination through idea, mind and psychological experience. Literature can be classified into several types, one of which is a novel that has developed more rapidly and more varied.

According to Nurgiyantoro (2005), said literature is essentially an image of life, a picture of life. Literature is a mirror or picture of reality. Because literature is a reflection of real life, it contains knowledge that can provide an understanding of life. That understanding comes from exploration of various forms of life in the form of discoveries and other information that can enrich the reader's knowledge. In other explanation, literature is a true picture or reflection of human's life. It describes what and how human life is and it usually reflects the events that happen 
in a society The one of kind this literary work much sought after by people in various circles is novel.

Novel in general, tells about story of the characters in everyday life and all the nature. And every each character have different problem. Usually the problem that is described in the story is the result of the author's experience. Many of the workers (in creating) theirs work are influenced by their personal life. Sometimes, even the characters in the works reflected their own personal characterization. Similar to opinion Dwitantyanov (2013), who said that literary work is reflection of real life in truth although reflection of real life has been mixed by imagination of the author. Every unsure develop of novel, the author try to make more unique with add emotion touch in every characterization of character and emotion through in every dialogs, and also words chosen actually is describe confusion and purity of inner's author. However, readers perceive a work was not released from their psychology personality.

Abraham Maslow formulated a theory of human motivation in which basic needs must be met by individuals. If the individual cannot fulfill his basic needs, the individual cannot fulfill his needs. The level of sequential needs according to Abraham Maslow as follows: psychological need, safety need, love and belongingness need, esteem need, and self actualization need. Where is if someone has reached the level of self actualization, the person became a complete human who gained unimaginable satisfaction. Humanistic theory is very concerned about the human dimension in dealing with its environment humanely by focusing on individual freedom to express opinions and determine their choices, values, responsibilities, goals and meanings, (Zukrin in Baharuddin 2007).

Based on the explanation above, the researchers is interested in analyze Maslow's hierarchy of needs described in the novel Great Gatsby. The novel itself tells about the true love and hope.

The Great Gatsby is a novel by F Scott Fitzgerald which tells about Jay Gatsby who tried to get all his needs, especially his love for Daisy. This novel was first published on 1925 in United States. Fitzgerald has written four novels 
throughout his life but the most famous and phenomenal is The Great Gatsby. Therefore, researchers are interested in analyzing the novel by giving the title "An Analysis of Maslow's Hierarchy of Need In The Great Gatsby Novel By Franciss Scott Fitgerald".

\section{RESEARCH METHOD}

This research used qualitative method. Qualitative method is a process of research and understanding based on methodology that investigated a social phenomenon and human problem. According to Creswell in Hardiansyah (2010) qualitative research is an inquiry process of understanding based on distinct methodological traditions of inquiry that explored a social or human problem, the researcher builds a complex, holistic picture, analyzed word, report detailed views of information, and conducted the studied in a natural setting. Qualitative method is emphasize with meaning and value and used to know the hidden meaning, to develop theory, and understand social interaction and human psychology.

In this research, the researchers used Abraham Maslow's Theory Hierarchy of Needs to analyze Maslow's needs depicted in F. Scott Fitzgerald's the Gatsby novel.

\section{RESEARCH FINDING AND DISCUSSION}

This chapter discussed about research findings. The findings displayed all results of data analysis. In this chapter, the researcher found the research question. To make it clear for the readers, the researcher conveys the discussion of the findings.

\section{A. Types Hierarchy of Human Need Abraham Maslow's}

In The Great Gatsby novel, Jay Gatsby as the main character with several priorities in his life from his childhood to his death, Jay Gatsby did his best to get everything he needed according to psychological needs, safety needs, love and belongingness and esteem need. In the data below, the researcher will explain Jay Gatsby's efforts to fulfill his psychological needs.

Maslow explaining in his theory that humans have five needs that are structured in a hierarchy, namely psychological needs, safety needs, love and 
belonging needs, esteem needs, and self-actualization needs. In explaining Abraham Maslow's theory, the need for self-actualization is the highest need. This need will be fulfilled if other needs below it have been fulfilled. The need for selfactualization is the highest inherent human need, capacity and potential for development. Maslow in Alderfer (2009) supports the theory of Abraham Maslow relating to the theory of human needs. The data below shows the needs of Jay Gatsby that have been fulfilled such as psychological needs, safety needs, love and belongingness needs and esteem needs.

\section{Psychological Need}

Psychological needs are the main needs and basic needs, needs such as food, water, and sleep. The data below are the needs that have been fulfilled by Jay Gatsby.

\section{Data 1:}

At nine o'clock, one morning late in July, Gatsby's gorgeous car lurched up the rocky drive to my door and gave out a burst of melody from its threenoted horn. (pg.41)

It was the first time he had called on me, though I had gone to two of his parties, mounted in his hydroplane, and, at his urgent invitation, made frequent use of his beach. (pg. 88-89)

Gatsby invited Nick to lunch together and Gatsby also asked Nick to try his luxury car and invited Nick to go the second time to a very festive party. The data above shows that Jay Gatsby has a luxurious life and has beautiful things and invites people to lunch, party, and enjoy what has been provided at his home. Needs commonly used as homeostatic starting points (efforts to maintain the balance of physical elements). Really these needs are the most important, basic, and strong of all needs, they are able to completely block every other need until the psychological needs have been met (Maslow in Alwisol 2009). Jay Gatsby buys what he wants to satisfy himself. And wealth is Gatsby's dream from childhood.

\section{Data 2:}

His parents were shiftless and unsuccessful farm people - his imagination had never really accepted them as his parents at all. (The Great Gatsby p.g 140)

\section{British, Jurnal Bahasa dan Sastra Inggris}


Based on psychological needs, the novel above explains how Jay Gatsby wanted to have a luxurious life even he always prided himself and said that he was born of the son of a rich man. And he said how he succeeded in everything. Fromm (2014) humanistic psychological theory states that behavior is acquired by conditioning People are dominated by their previous experiences in their natural world. In experiencing new environments and information, people must modify, add to, or change their previous experiences. This is controlled by their mental orientation and character which helps them assimilate and accommodate new environments. On the other hand Jay Gatsby was a poor man, he left his family to pursue the opportunity to become rich for a year he traveled along the coast and he lived a rough and happy life with women and he just waited for his success to laze around.

\section{Safety Need}

Safety needs are important needs that must be fulfilled after psychological needs are met. Safety needs themselves are the need for security, stability, freedom, protection, dependence, not feeling fear, chaos, structure, law, order, strength and protection and others.

\section{Data 3:}

As soon as I arrived I made an attempt to find my host, but the two or three people of whom I asked his whereabouts stared at me in such an amazed way, and denied so vehemently any knowledge of his movement (pg.57)

Jay Gatsby held a party at his house for a long time, but he never showed who he was to the guest he invited. Therefore many people talk about things that are not good. According to Maslow (1994) safety this is a need such as protection from danger, being confident and not feeling afraid.

\section{Data 4:}

"Gatsby. Somebody told me - " The two girls and Jordan learned together confidentially. "somebody told me they thought killed a man once. "I don't think it's so much that, "argued Lucille skeptically; " it's more that he was a Germany spy during the war." (pg. 60)

Jay Gatsby covers himself with others, giving rise to speculation about him thinking negatively about him. Many were suspicious including Jordan's friend 
Daisy that he was hiding because he covered his past identity, his origin, his job, and his personal life. Safety needs can also develop according to social problems or the conditions of the country where they live (Maslow in Yusuf et.al 2008). Jay Gatsby keeps his identity clear because he doesn't want people to think more about him in the past.

\section{Love and Belongingness Need}

Need love of love and belonging is a need that encourages a person to make an effective and emotional relationship in another person or group in the community. The goal is because they are lonely, isolated, and helpless if their spouse, friends or family they leave behind. Researchers find data related to love and ownership.

\section{Data 5:}

"It was a strange considence," I said. "But it wasn't a considence at all." "Why not?" "Gatsby bought that house so that Daisy would be just across the bay." (pg.110)

Jay Gatsby's attempt to get love from Daisy Jay Gatsby lives near Daisy precisely in the castle across the bay from his house Daisy. Hoping for his love, Jay Gatsby held a festive party every weekend so Daisy came to the party. Maslow (1994) When people want to express their love for someone or something they like not only love, people also want to be part of what love is and there is always motivation for it. The form of Jay Gatsby's love for Daisy was to build a house right next to his daisy house.

\section{Data 6 :}

"He wants to know," continued Jordan. "if you'll invite Daisy to your house some afternoon and then let him come over. "The modesty of the demand shook me. He had waited five years and bought a mansion where he dispensed starlight to casual moths - so that he could "come over" some afternoon to a stranger's garden. (p.g 111)

Based on the data above, Jay Gatsby tried to meet Daisy but five years ago the separation of Daisy and Jay Gatsby made Jay Gatsby nervous and strange. So Jay Gatsby asks Nick to invite Daisy to drink tea at her call house so Jay Gatsby can meet Daisy. The need for love and ownership is a need that encourages a 
person to make an effective and emotional relationship with other people in the family or group in a society (Maslow 1994).

\section{Esteem Need}

All human beings have needs to be respected and respect for others. People need to involve themselves in gaining recognition and having activities that make the person feel a contribution. These needs are divided into the first several parts, consisting of the desire for strength, achievement, adequate mastery, indenensiens, and freedom, embracing the world, competence, and self-confidence. Secondly, the needs expressed to gain respect from others such as fame and glory, reputation, status, dominance, interests and awards.

\section{Data 7:}

"I'm Gatsby," he said suddenly. "What!'Iesclaimed."'oh, I beg your pardon."I tought you knew, old sport. I'm afraid I'm not a very good host." He smiled understandingly - much more than understandingly. It was one of those rare smiles with a quality of eternal reassurance in it, that you may come across four or five times in life. It faced - or seemed to face - the whole external world for an instant, and then concentrated on you with an irresistible prejudice in your favor. It understood you just so faras you wanted to be understood, believe in you as you would like to believe in yourself, and assured you that it had precisely the impression of you that, at your best, you hoped to convey. Precisely at that point it vanished - and I was looking at an elegant young rough neck, a year or two over thirty, whose elaborate formality of speech just missed being absurd. Some time before he introduced himself I'd got a strong impression that he was picking his word with care.(pg. 66-67)

Jay Gatsby shows himself in the Nick which fascinates him, in this novel Jay Gatsby is known to be relaxed and easy to get along with other people. When I was waiting at the library door hall, Jordan the baker and the gatsby came out together. When I greeted Jordan, he seemed to formally greet me and others. Alwisol (2009) says People need to involve themselves in gaining recognition and having activities that contribute to their feelings. Jay Gatsby was formal to the person who met him because he wanted to get respect.

\section{Data 8:}

"Well, I'm going to tell you something about my life", he interrupted. "I don't want you to get a wrong idea of me from all these stories you hear. " (pg. 90) 
Jay Gatsby knew about rumors circulating about him that were not good, so he convinced Nick not to misunderstand him even though he made false stories about himself to his nick. Maslow in Yusuf et.al (2008) said, needs expressed to gain respect from others, such as: status, reputation, fame and glory, dignity, dominance, interests, and awards These needs are classified into additional parts of need Jay Gatsby convinced Nick not to believe about rumors that were not good about him so he got the honor of Nick.

\section{Self Actualization Need}

The need for self-actualization is the highest human need. A person will be able to achieve self-actualization if they can get their own time and obstacles. Internal barriers such as being alert, afraid, ashamed, and so on. External barriers such as loss of opportunity, discrimination, and repressive attitudes in the environment. another thing that happened to Jay Gatsby there are obstacles so that Jay Gatsby cannot meet the needs of actualization needs both inside and outside obstacles like there are 2 needs that cannot be fulfilled namely the need for safety and love and belongingness including Gatsby cannot meet the needs of his love for daisy, losing his safety when he was alive, discovered the fact that Daisy never love Gatsby.

Humans as unique individuals need feelings from those who love them. A perceived situation is a form of need that every individual wants to fulfill during his lifetime. Another thing that happened to Gatsby, he could not fulfill his love for Daisy. Daisy is the first love Gatsby left behind because Gatsby was at war, because Gatsby never returned eventually Daisy was married by Tom Buchanan, a wealthy and influential man at the time. Not accepting that Daisy was with Tom, Gatsby used her social power and position to marry Daisy. but it was only in vain that Gatsby did not get Daisy's love even before he died. As shown in the data below.

\section{Data 9:}

"Your wife doesn't love you," said Gatsby. "She's never loved you. She loves me."(P.84).

"Oh, you want too much!" He exclaimed to Gatsby. stop it Gatsby! I can't help what was past, "He began to sob helplessly. And only looked at their faces. (P. 84).

\section{British, Jurnal Bahasa dan Sastra Inggris}


Based on the explanation, Jay Gatsby told Tom that Daisy did not love him but Tom did not believe what Jay Gatsby said, because of that Jay Gatsby encouraged Daisy to tell her husband, Tom Buchanan, that he had never loved him. After a few minutes Daisy did not told Tom what had happened to them both, and that proved that Daisy didn't really like Jay Gatsby. Finally the night passed without any clarity between the three of them. In Maslow's theory (1961), he postulates that an insatiable need creates a person doing something in an organism and functions as a force to direct its behavior. Not only did he lose his love as long as he was alive but Jay Gatsby lost his safety and the data shown below.

\section{Data 10:}

The chauffeur - he was one of Wolfsheim's proteges - heard the shots afterward he could only say that he hadn't thought anything much about them. I drove from my station directly to Gatsby's house and my rushing anxiously up the front steps was the first thing that alaremed any one. But they knew then, I firmly believe. With scarcely a word said, four of us, the chauffeur, butler, gardener, and I, hurried down to the pool. (pg. 103)

The cause of Jay Gatsby's death began with Jay Gatsby and Daisy returning from the plaza hotel. Where between Tom Buchanan, Daisy and Jay Gatsby had a problem regarding their relationship, Daisy and Jay Gatsby decided to leave the hotel by driving Jay Gatsby's car but the driver was not Jay Gatsby but Daisy. Daisy drove the car emotionally and was so brutally accidental when Daisy crashed into a woman named Myrtle and the woman edited. The Mrytle husband named Wilson is looking for a car to get revenge. According to Maslow in Freud (1987), humans are not as empty organisms, but as active beings whose behavior is driven by several powerful forces. These are called forces based on organic needs. Myrtle's husband learns that the owner of the car is Jay Gatsby and he returns to Jay Gatsby and shoots him next to the pool.

\section{CONCLUSION AND SUGGESTION}

The great Gatsby novel, written by Francis Scott Fitzgerald, portrays 19th century life in America precisely, in 1920 with Jay Gatsby as the main character in the novel. The theory of needs by Abraham Maslow, the researcher uses, 
describes five human needs that physiologically affect human life, namely physiological needs, safety needs, love and belonging needs, esteem needs and self-actualization needs. Based on the theory of needs above, Jay Gatsby as the main character can be said as a human with several needs in his life, ranging from childhood to adulthood, such as psychological needs, safety needs, love and belonging needs, esteem need. but there is a need that cannot be achieved by Jay Gatsby namely safety needs and love and belongingness so that the actualization needs cannot be reached. In this study, researchers are only trying to find out Maslow's needs described in the Gatsby novel by F Scott Fitzgerald.

\section{REFERENCES}

Alwisol. 2004. Psikologi Kepribadian. Malang: UMM Press. 2009. Psikologi Kepribadian. Malang: UMM Press.

Baharuddin, Zukrin. 2007. Pendidikan Humanistik. Yogyakarta: Ar Ruzz Media

Cresweel, John W. 2003. Research Design Qualitative, Quantitave, And Method Approached. Sage Publication, Inc : California.

Dwitantyanoov, S. 2013. Literary work. 261137 -literature -on-student -book and -its-effec-e297ba5e. pdf. Acced on March 17, 2019 at13.45.

Erich Fromm's, dkk. 2014. The Greatness and Limitations of Erich Fromm's humanism. Fromm's Humanis. Contemporary Psychoanalysis.

Maslow, Abraham (1961): 20. Http:// Www. Pursuit- Of- Happiness. Org/ History- Of-Happiness/ Abraham- Maslow/ Accesed On 19 August 2018 At 1750 .

1994. A Theory of Human Motivation. Network of automa TE library. . 1987. Toward A Psychology of Being Second Edition Abraham H. MasloW. New York :Van Notrand Reinhold Inc.

Nurgiyantoro, Burhan. 2005. Teori Pengkajian Fiksi. Yogyakarta: Gadjah University Press.

Wellek, Rene dan Warren Austin. 1993. Teori Kesusastraan (terjemahan melalui Budiyanto). Jakarta: Gramedia.

Yusuf, dkk. 2008. Teori Kepribadian. Bandung: PT. Remaja Rosdakarya 